\title{
IMPACTS OF URBANIZATION ON CARNIVORE MAMMALS IN JAMMU AND KASHMIR, INDIA
}

\author{
Rahul Kait ${ }^{1}$ *and D.N Sahi ${ }^{2}$ \\ ${ }^{1}$ Department of Zoology, GDC R. S. Pura, Jammu, India \\ ${ }^{2}$ P.G. Department of Zoology, University of Jammu, Jammu 180006, India \\ *E-mail: rahulkait09@yahoo.com
}

\begin{abstract}
During present study, from 2004 to 2006 in Jammu district and 2006 to 2009 in Trikuta hills, the impact of urbanization on carnivores was studied. Order Carnivora is represented by 5 species. Their local and national/global status was also determined. It was also found that urbanization is taking place by leaps and bounds which has affected wildlife of the area most by habitat destruction, habitat fragmentation and noise. It has been found that the most effected order in the mammals is carnivora, because of the requirement of the larger habitat for fulfilling their needs.
\end{abstract}

Key words: Trikuta hills, carnivore, urbanization, shivaliks, habitat fragmentation.

\section{INTRODUCTION}

With the increase in human population, their needs have also increased, and they developed the technology that is helping in extraction of natural resources which is degrading the environment. Land is being transformed for construction of roads, housing colonies, towns and cities. Number of motor vehicles has increased, and factories and industries are polluting the environment. These changes deprive the wild animals continuously of their natural habitat and the environment. Urbanization is leading to habitat fragmentation. The classic view of habitat fragmentation is the breaking up of a large intact area of a single vegetation type in to smaller intact units (Alan $e t$ al. 2002). Hence, present work was undertaken in Jammu and Kashmir state of India with the objectives: (i) prepare an inventory of carnivore mammals, and (ii) determine the effect of development (urbanization) on the wild carnivore mammals in Jammu district.

\section{MATERIALS AND METHODS}

Erstwhile Jammu district is situated between $74^{\circ} 19^{\prime} \mathrm{E}$ and $75^{\circ} 20^{\prime} \mathrm{E}$ longitudes and $32^{\circ} 27^{\prime} \mathrm{N}$ to $33^{\circ} 50^{\prime} \mathrm{N}$ latitudes and at an altitude ranging from $340-410 \mathrm{~m}$ asl. It is $2,942 \mathrm{sq} \mathrm{km}$ and is surrounded by district Kathua, Udhampur and Rajouri. District Jammu is located on alluvial plains and foot hills of Shivaliks. Trikuta hill lies in the Erstwhile District Udhampur and presently in the District Reasi of Jammu and Kashmir of India. Forests of study area are typical subtropical. Lower altitudinal zone is dominated mainly by scrubs with a few scattered patches of broad leaved trees. On moderate elevation, these scrubs are found to be mixed with broad leaved and chir pine communities, while high elevations are dominated exclusively by chir-pine patches. There are four well defined seasons: winter (mid November to March), summer (March to end of June), monsoon (July to September) and autumn (October to mid November). 


\section{METHODS}

Following methods were employed to record wild carnivore mammals:

Road side surveys were made in the study area, mammals were observed with naked eye, and through $7 \times 50$ prismatic fields Binocular (Bushnell make) during early morning and evening when the traffic and disturbance is minimum. For the identification of carnivore mammal's field diagnosis, character and colorful plates by Prater (1971) have been used. Hunters, villagers, nomads were asked about the presence and absence of particular species in the area. Burrows, bones, feaces, pellets and signs of destruction of habitat were also recorded for the presence of particular animal species. Small carnivore mammals of order Carnivora were collected by rodent traps.

Following terms were used for determining local status:

Common: species seen or evidence recorded only once per visit a day.

Uncommon: species fairly well distributed seen once a week.

Occasional: restricted distribution, sighted or evidence recorded once a week.

Rare: fewer than 10 sightings or single evidence recorded from reliable source during study period (Srinivasulu and Nagulu 2002).

\section{RESULTS AND DISCSSION}

Order Carnivora is represented by 5 species; Panthera pardus (leopard), Canis aureus (Asiatic jackal), Viverricula indica (small Indian civet), Herpestes edwardsii (common mongoose) and Herpestes auropunctatus (small indian mongoose) belonging to 4 genera and 4 families. Local status of the order Carnivora reveals that two species are rare and rest three species are uncommon. The national/global status showed that one species is vulnerable, one species is lower risk near threatened and the rest three are lower risk least concerned (Table 1).

Leopard is rare in the study area due to habitat loss by deforestation and fragmentation and due to scarcity of prey species in the area. Leopard was reported from whole of the south Asia by Pocock (1939). Brander (1982) reported that male mostly remains with female. This observation could not be confirmed during the study period.

Small Indian Civet is uncommon in the study area. It is nocturnal and found throughout the study area (Akhnoor, Sidhra, Surinsar, Nagrota, Samba, R.S. Pura,Katra, Reasi, and through out the Trikuta hills). It prefers scrubby forests and bushy grasslands, and lives in holes, under rocks and near human habitation. Negi (1992) reported that it prefers habitat with tall grasses. In the study area they face the scarcity of water. This is evident from the fact that during the study period two cats were found dead in the artificial water tanks in the Environmental Park. Thus, water in this area is a limiting factor. Civets being carnivore have larger home range and fragmentation of their habitat due to construction of roads lead to the frequent accidental killings. Chakraborty (1983) reported it from Peninsular India and Sri Lanka, thus has wide range of distribution.

Common mongoose Herpestis edwardsii is uncommon in study area. They are generally found in pairs, but sometimes singly. Parents prefer to stay with young ones and two groups of six each (2 parents and four young ones) which lived in Roopnagar and Rehari area of Jammu city were seen many times during study period. Pocock (1941) reported the common mongoose from north India and Nepal. 
Table 1. Showing checklist, Local status and National or Global status of mammals of Study Area.

\begin{tabular}{|l|l|l|c|c|}
\hline Family & \multicolumn{1}{|c|}{ Common Name } & \multicolumn{1}{|c|}{ Zoological Name } & $\begin{array}{c}\text { Local } \\
\text { Status }\end{array}$ & $\begin{array}{c}\text { National } \\
\text { Global Status }\end{array}$ \\
\hline Carnivora & & & & \\
Felidae & Leopard & Panthera pardus(Linnaeus) & $\mathrm{R}$ & VU \\
Canidae & Asiatic Jackal & Canis aureus (Linnacus) & $\mathrm{UC}$ & LRlc \\
Viverridae & Small Indian Civet & Viverricula indica (Desmaresti) & $\mathrm{UC}$ & LRnt \\
Herpestidae & Common Mongoose & Herpestes edwardsii (Nyula Hodgson) & $\mathrm{UC}$ & LRIc \\
& Small Indian Mongoose & Herpestes auropunctatus (Hogson) & $\mathrm{R}$ & LRIc \\
\hline
\end{tabular}

Common-C, Uncommon-UC, Occasional-O, Rare-R, VU-Vulnerable, LRnt-Lower Risk near threatened, LRIc- Lower Risk least concerned

National or Global status derived using the 1994 IUCN Red list criteria.

Small Indian mongoose (H. auropunctatus) is very rare and is seen only once during the study period. It is smaller in size as compared to common mongoose, in looks it is replica of common mongoose. It lives in forests, bushes and grasses near human habitation. Chakraborty (1983) reported it from Manipur, South of Ganga, Orissa, Bhutan and Bangladesh.

Indian Jackal (Canis aureus) is found through out the district, it has been seen solitary and in groups of two and four. A single Jackal was observed eating carcasses of cattle on the bank of river Tawi near Sidhra Bridge. They also lift, fowls and lambs from the villages. Brander (1982) reported that Jackal chiefly consort in pairs and live round the villages.

With the increase of human population and urbanization the wildlife habitat has been destroyed for one or other reason. Horizontal expansion of the cities and towns such as Roop Nagar, Bantalab, Janipur, Sidhra Bypass, Narwal and Kotbalwal in Jammu, and Katra and Reasi in Trikuta hills, has resulted in the shrinkage of wildlife habitat as all these areas were known for their wilderness.

Not only expanding cities are responsible for shrinkage of the wildlife habitat, but forests are destroyed for road makings and establishing factories etc. The construction work of the Railway tract from Jammu to Kashmir has added to the miseries of not only carnivore mammals but whole flora and fauna. Second tract to Mata Vashnoo Devi has ristricted the movement of the all mammals.

Not all the species of the mammals are declining due to urbanization but few species which are commensal and which have increased in number such as Rattus rattus, Mus musculus. Bandicota indica, Bandictoa benglanses and monkeys; but other species belonging to Artiodactyla, Carnivora lagomorpha have declined to the considerable extent due to urbanization.

\section{REFERENCES}

Alan, B., B. Franklin, R. Noon and G.T. Luke. 2002. What is Habitat Fragmentation? Studies in Avian Biology 25:20-29.

Brander, A.A.D. 1982. Wild Animals in Central India. Natraj Publs., Dehradun, India.

Chakkarborty, S. 1983. Contribution to the knowledge of mammalian fauna of $J$ and $K$. Ind. Roc. Zool. Surv. Ind. Occ. Paper No. 38:129. 
Negi, S.S. 1992. Himalayan Wildlife, Habitat and Conservation. Indus Publishing Company, New Delhi.

Pocock, R.I. 1939. The Fauna of India including Pakistan, Burma and Ceylon, Mammalia (Vol. I). Government of India, Delhi.

Pocock, R.I. 1941. The Fauna of India including Pakistan, Burma and Ceylon, Mammalia (Vol. II). Government of India, Delhi.
Prater, S.H. 1971. Indian Animals. J. Bomb. Nat. Hist. Soc. (Third revised edition), India.

Srinivasulu, C. and V. Nagulu. 2002. Mammalian and Avian diversity of the Nallamala Hills, Andhra Pradesh. J. Zoos Print 17(1):675-684. 